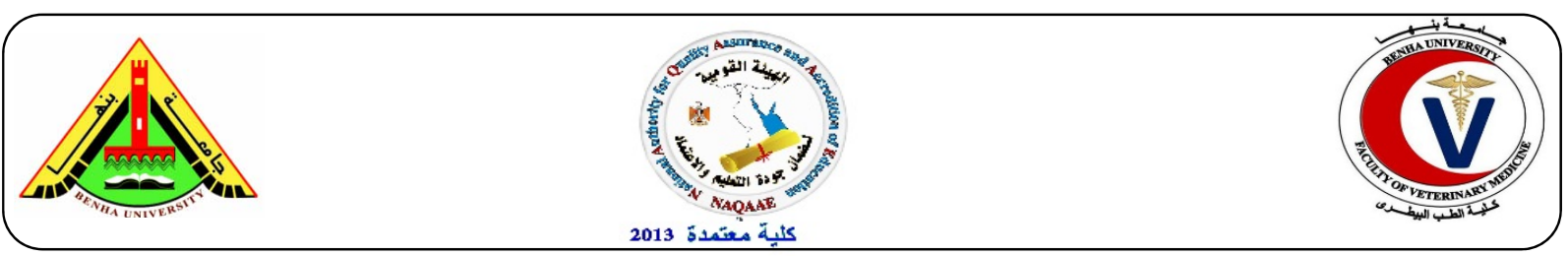

\title{
Survival of Escherichia coli 0157:H7 during processing and ripening period of Keş Cheese
}

\author{
Özen Kurşun Yurdakul ${ }^{a}$, Seval Sevgi Kırdar ${ }^{b}$, Aylin Kasımoğlu Doğrư ${ }^{c}$, Erhan Keyvan ${ }^{a^{*}}$ \\ ${ }^{a}$ Department of Food Hygiene and Technology, Faculty of Veterinary Medicine, Mehmet Akif Ersoy University, Istiklal \\ Campus, 15030 Burdur, Turkey. \\ ${ }^{b}$ Department of Food Processing, Milk and Dairy Products Technology Programme, Mehmet Akif Ersoy University, \\ Istiklal Campus, 15030 Burdur, Turkey. \\ ${ }^{c}$ Department of Food Hygiene and Technology, Faculty of Veterinary Medicine, Kirıkkale University, 71450 Kırıkkale, \\ Turkey. \\ *Author for correspondence: Asst. prof. Erhan KEYVAN. Tel: +90 24821321 27. Fax: +90 24821320 01. e-mail: \\ erhankeyvan@mehmetakif.edu.tr. Adress: Department of Food Hygiene and Technology, Faculty of Veterinary \\ Medicine, Mehmet Akif Ersoy University, Istiklal Campus, 15030 Burdur, Turkey
}

\section{A B S T R A C T}

In this study the survival of Escherichia coli O157:H7 during the production process and ripening period of Keş cheese was investigated. Three vats containing equal amounts of raw milk were inoculated with $10^{2}, 10^{4}, 10^{6} \mathrm{cfu} \mathrm{mL}^{-1} \mathrm{E}$. coli O157:H7, respectively andone vat remained uninoculated. Keş cheese was produced from both inoculated and uninoculated milks with the traditional method of the region. Cheese samples ripened at $6^{\circ} \mathrm{C}$ for 90 days and E. coli O157:H7 enumarations were done from uninoculated milk, inoculated milks, curds and different stages of ripening period. Most Probable Number technique was used for the analysis of E. coli O157:H7. Classical culture methods were used for the detection of aerobic mesophilic bacteria, lactococci and coliform bacteria. Also, control cheese was analysed for dry matter, salt content in dry matter and $\mathrm{pH}$ value. Elimination times were 45 days for $10^{2} \mathrm{cfu} \mathrm{mL}^{-1}, 75$ days for $10^{4} \mathrm{cfu} \mathrm{mL}$ ${ }^{1}$, and 90 days for $10^{6} \mathrm{cfu} \mathrm{mL}^{-1}$ of E. coli $\mathrm{O} 157: \mathrm{H} 7$. The final dry matter, salt content in dry matter and $\mathrm{pH}$ value were $82.52 \%, 3.16 \%$ and 4.58, respectively. Consequently, Keş cheese should be ripened at least 90 days in order to be considered as safe for public health.

Keywords: Elimination times, Escherichia coli O157:H7, Keş cheese, traditional cheese, dairy producs

(http://www.bvmj.bu.edu.eg)

(BVMJ-32(1): 83 -88, 2017)

\section{INTRODUCTION}

Escherichia coli O157:H7 has been an important role as a foodborne pathogen since it was identified in 1982 for the first time (Riley et al. 1983). The main symptom of the disease of EHEC is hemorrhagic colitis (HC) referred as bloody diarrhea (Coia et al. 1998). It was reported that cattle, especially dairy cows, were the main reservoir, followed by sheep and pigs (Zhao et al. 1995). Also, outbreaks are though to be occurring due to faecal contamination originated from cattle (Wang et al. 1996). Dairy products made with raw milk and/or insufficiently heated milk can cause outbreaks (Honish et al. 2005; Oksuz et al. 2004). Cultured dairy products may be a high risk group for $E$. coli $\mathrm{O} 157: \mathrm{H} 7$ infections above human being. E. coli $\mathrm{O} 157: \mathrm{H} 7$ was reported to persist in white cheese for 120 days (Kuplulu et al. 2000), cheddar cheese for 158 days (Reitsma et al. 1996), smear- ripened cheese for 90 days (Maher et al. 2001) and camembert cheese for 75 days (Ramsaran et al. 1998). Keş cheese is a traditional cheese in Turkey and produced in different regions especially in the Mediterranian region. However there are differences in production this cheese even within the same region. In Burdur, Keş cheese is homemade cheese sold in bazaars. Commonly, Keş cheese's production process contains boiling raw milk, cooling and boiling lactic coagulum steps, without adding any spices (Tarakc1 et al. 2010). But in Burdur (in Mediterranean region of Turkey), Keş cheese is produced with self-coagulation of raw milk without any starter culture addition, than cutting coagulum, draining curd, kneading the curd with a mixture of spices such as nigella, cumin, red pepper, and black pepper. In this production process of Keş cheese, natural flora of raw milk 
plays an important role in the formation of ripening. Considering that Keş cheese is commonly consumed in Burdur (Kirdar 2004) and this cheese has no pasteurisation and/or boiling stages in production process, it becomes very important to draw attention to potential risks in terms of public health. Also, due to handmade production human sourced contaminations are unavoidable.

Therefore, this study was conducted to determine the survival of E. coli O157:H7 in Keş cheese during production stages and ripening period.

\section{MATERIALS AND METHODS}

\subsection{Test strain}

As preliminary study, E. coli O157:H7 detection was done in 33 bulk tank bovine milks in order to isolate E. coli $\mathrm{O} 157: \mathrm{H} 7$, but none of the samples were positive. Considering human sourced contaminations, a human strain E. coli O157:H7 (ATCC 35150) was used in this study. The E. coli O157:H7 ATCC 35150 test strain was obtained from the Institute of Refik Saydam Hifzissihha (Ankara, Turkey) and kept in cryogenic vials at $85^{\circ} \mathrm{C}$ until use. Then at the start of the experiment, ATCC 35150was activated in tryptic soya broth (TSB; BD Diagnostic Systems, Sparks, MD, USA) at $37^{\circ} \mathrm{C}$ for $24 \mathrm{~h}$.

\subsection{Cheese production}

Sixty liter antibiotic-free bovine milk ( $\mathrm{pH}$ 6.8) was taken from the milk producing farms in Burdur. Firstly, raw milk analysed for the E. coli O157:H7 presence. None of the raw milks were harboured E. coli O157:H7 that used for all three trials to produce Keş cheese. For Keş cheese production, milk was heated to $32{ }^{\circ} \mathrm{C}$ and transferred to stainlesssteel cheese vats, each containing $15 \mathrm{~L}$ of milk. Three vats were inoculated with $10^{2}, 10^{4}$ and $10^{6} \mathrm{cfu} \mathrm{mL}{ }^{-1}$ reference strain. One vat was not inoculated with $E$. coli O157:H7 and used as control. Chymosin was not added. Vats were kept under sunshine until lactic coagulum formed (about 8 hours). The coagulum was cut into 2 or 3 curds, then the curds were transferred to cheese cloth and drained in cool room $\left(15^{\circ} \mathrm{C}\right)$ for 24 hours. Drained curds were crumbled and solid salt $(2 \%)$, nigella $(1 \%)$, cumin $(1 \%)$, and red pepper $(1 \%)$ were added. The amount of spice mixture was decided according to the suggestion of the regional dairies that produce Keş cheese. Afterwards, the curd was kneaded manually for 5 minutes to distribute the salt and spices uniformly throughout the curd. The curd was shaped into cubic or colonical form and dried at room temperature $\left(25^{\circ} \mathrm{C}\right)$ for 4 days. After the fifth day, cheeses ripened at $6{ }^{\circ} \mathrm{C}$ for 90 days. Experimental Keş cheese productions were replicated three times.

\subsection{Sampling}

Twenty five milliliter raw milk sample taken from uninoculated milk and the Most Probable Number (MPN) technique was used for E. coli O157:H7 enumaration, For the same purpose, 10 $\mathrm{mL}$ samples taken from $10^{2}, 10^{4}, 10^{6} \mathrm{cfu} \mathrm{mL}^{-1} \mathrm{E}$. coli O157:H7 inoculated milks, $10 \mathrm{~g}$ samples taken from curds $\left(8^{\text {th }} \mathrm{h}\right.$ of production $)$, drained curds $\left(24^{\text {th }}\right.$ $\mathrm{h}$ of production), dried cheeses in the fifth day of production, $1^{\text {st }}, 7^{\text {th }}, 15^{\text {th }}, 30^{\text {rd }}$ days of ripening period of cheese and classical culture method was used. After 30 days of ripening period, to ensure recovery of levels of the pathogen, Most Probable Number technique was used for $60,75,90$ day cheese samples. Also, classical culture methods were used for aerobic mesophilic bacteria, lactococci and coliform bacteria enumarations. For the compositional analysis and $\mathrm{pH}$ measurements, cheese samples were taken at 1,30,60, and 90 days of ripening.

\subsection{Microbiological analysis}

For the classical culture method enumeration of E. coli $\mathrm{O} 157: \mathrm{H} 7$, inoculated milk $(10 \mathrm{~mL})$, curd $(10 \mathrm{~g})$ and cheese $(10 \mathrm{~g})$ samples were diluted with $90 \mathrm{~mL}$ of $0.1 \%$ peptone water and homogenized for 2 minutes with a Labblender 400 stomacher (Seward Laboratory, London, UK). Serial dilutions were prepared with $9 \mathrm{~mL}$ sterile peptone water. Each dilutions were $0.1 \mathrm{~mL}$ spread onto a sorbitol MacConkey agar (Oxoid) plate, containing 0.1\% 4methylumbelliferone-b-d-glucuronide (SMAMUG) in duplicate and incubated at $37{ }^{\circ} \mathrm{C}$ for 18 $\mathrm{h}$. Suspicious colonies which were MUG and sorbitol negative were confirmed by $E$. coli O157:H7 latex agglutination assay (Oxoid). O157 and H7 antisera (BD Diagnostic Systems) were used to identify presumptive E. coli O157:H7 isolates for further accurate isolation. To determine the levels of $E$. coli $\mathrm{O} 157: \mathrm{H} 7$ that under the detection limit $\left(<1.0 \times 10^{1} \mathrm{cfu} \mathrm{mL}^{-1} \mathrm{MPN}\right.$ technique was used. For this purpose, cheese samples $(1 \mathrm{~g})$ were transferred into three tubes each containing 9 $\mathrm{mL} \mathrm{mEC}$ (E. coli) broth (BD Diagnostic Systems) supplemented with novobiocin (Sigma, St Louis, MO, USA). Similarly, decimal dilutions of the samples were added to three tubes of $\mathrm{mEC}$ broth $(9$ $\mathrm{mL}$ ). All tubes were incubated at $37^{\circ} \mathrm{C}$ for $24 \mathrm{~h}$. After incubation, enriched cultures $(0.1 \mathrm{~mL})$ were inoculated on SMA-MUG plates in duplicate and incubated at $37{ }^{\circ} \mathrm{C}$ for $18 \mathrm{~h}$. Typical E. coli O157:H7colonies were selected and confirmed 
according to the procedures described above. Evaluation of MPN results were done according to the FDA Bacteriological Analytical Manual (FDA 1984).

To determinate the number of other bacteria, 10 $\mathrm{g}$ cheese sample was prepared according to the procedures described above and $0.1 \mathrm{~mL}$ spread plate method was used. Plate count agar (Oxoid, Basingstoke, England), De Man Rogosa Sharp agar ( $\mathrm{pH}$ 5.4, Oxoid), M17 agar (Oxoid), violet red bile agar (Oxoid) were used for the isolation of aerobic mesophilic bacteria (aerobically at $30{ }^{\circ} \mathrm{C}$ for $48 \mathrm{~h}$ ), Lactobacillus (anaerobically -GasPak System, Oxoid- at $37{ }^{\circ} \mathrm{C}$ for 3 days), Lactococci (aerobically at $37{ }^{\circ} \mathrm{C}$ for $48 \mathrm{~h}$ ) and coliform bacteria (aerobically at $37{ }^{\circ} \mathrm{C}$ for $48 \mathrm{~h}$ ), respectively.

\subsection{Compositional analysis}

Salt content and moisture content of cheese samples were analysed according to the IDF standard methods (IDF 1958; IDF 1988). pH values of samples were directly measured by $\mathrm{pH}$ meter (900 NEL brand $\mathrm{pH}$ meter) by dipping into the cheese.

\subsection{Statistical analysis}

All statistical analysis were performed using SPSS version 15.0 (SPSS 1999). The normally distributed data is presented as mean \pm standard deviation (SD) and non-normally distributed data is expressed as median (25\%-75\%). According to the data distribution, Pearson or Spearman correlation methods were used for correlation analyses. A $p$ value of $<0.05$ was accepted as statistically significant.

\section{RESULTS AND DISCUSSION}

Microbiological changes of the control Keş cheese flora are shown in Table I. The number of aerobic mesophilic bacteria, lactococci and Lactobacillus spp. increased until $30^{\text {th }}$ day of ripening, then they slowly decreased until at the end of ripening. Likewise, the number of coliform bacteria increased during production process, then they showed a strong decreasing. The increment of bacterial flora might be due to the fermentation of lactose while the reduction may be attributed to the decrease of $\mathrm{pH}$ level. On the other hand, microbiological results of the present study for total bacterial count, lactic acid bacteria, and coliform bacteria were differ from other studies (Akyuz and Gulumser 1987, Tarakc1 et al. 2001). These differences may be caused by differences between production process such as boiling or not boiling milk.

The changes in E. coli O157:H7 populations in Keş cheese are shown in Fig. 1. In all inoculated groups, while E. coli O157:H7 levels remained stable during the production process (5 days), E. coli O157:H7 counts were increased about $1 \log$ from the initial numbers of $10^{2}, 10^{4}$ and $10^{6} \mathrm{cfu} \mathrm{mL}^{-}$ ${ }^{1}$ during formation lactic koagulum $(8 \mathrm{~h})$. Then $E$. coli O157:H7 bacterial cells began to decrease in all groups at the first day of ripening. The average $\mathrm{pH}$ levels were determined as $\mathrm{pH} 6.80,5.24,4.87$ for uninoculated milk, lactic coagulum and curd, and first day of ripening, respectively. The increase and decrease of E. coli O157:H7 counts might be both explained by $\mathrm{pH}$ levels.

Growth of E. coli O157:H7 during cheese production was reported by many researchers previously. Reitsma and Henning (1996) stated that the pathogen grew during the production of cheddar cheese. Arocha et al. (1992) stated that $E$. coli $\mathrm{O} 157: \mathrm{H} 7$ grew from the inoculation level of 5 $\log$ cfu $\mathrm{mL}^{-1}$ to $7 \log$ cfu $\mathrm{g}^{-1}$ during the production process of fresh cottage cheese. Ramsaran et al. (1998) expressed that a significant increase in the number of $E$. coli $\mathrm{O} 157: \mathrm{H} 7\left(10^{4} \mathrm{cfu} \mathrm{mL}^{-1}\right)$ during the production of Camembert cheese.

Table I. Microbiological flora of Keş cheese during manufacturing and ripening (90 d).

\begin{tabular}{|c|c|c|c|c|c|c|c|c|c|c|c|}
\hline \multirow{2}{*}{$\begin{array}{l}\text { Bacteria } \\
\left(\log \mathrm{cfu} \mathrm{g}^{-1}\right)\end{array}$} & \multicolumn{3}{|c|}{ Production (hour) } & \multicolumn{8}{|c|}{ Ripening (Days) } \\
\hline & $\begin{array}{c}\text { Milk } \\
\left(\mathrm{mL}^{-1}\right)\end{array}$ & $\begin{array}{l}\text { Curd } \\
(8 \mathrm{~h})\end{array}$ & $24 \mathrm{~h}$ & 1 & 7 & 15 & 30 & 45 & 60 & 75 & 90 \\
\hline $\mathrm{AMGC}^{\mathrm{a}}$ & $6.7 \pm 0.1$ & $8.6 \pm 0.3$ & $8.6 \pm 0.1$ & $8.8 \pm 0.1$ & $9.4 \pm 0.1$ & $9.7 \pm 0.1$ & $8.9 \pm 0.1$ & $8.8 \pm 0.1$ & $8.5 \pm 0.2$ & $8.2 \pm 0.2$ & $7.7 \pm 0.4$ \\
\hline $\mathrm{LC}^{\mathrm{b}}$ & $5.3 \pm 0.6$ & $7.3 \pm 0.8$ & $7.5 \pm 0.7$ & $7.6 \pm 0.6$ & $8.2 \pm 0.6$ & $8.8 \pm 0.5$ & $7.9 \pm 0.2$ & $7.7 \pm 0.2$ & $7.6 \pm 0.6$ & $7.7 \pm 0.2$ & $7.6 \pm 0.3$ \\
\hline $\mathrm{LB}^{\mathrm{c}}$ & $5.1 \pm 0.3$ & $7.4 \pm 0.7$ & $7.2 \pm 0.4$ & $7.5 \pm 0.6$ & $7.9 \pm 0.4$ & $8.8 \pm 0.1$ & $7.8 \pm 0.3$ & $7.9 \pm 0.7$ & $7.8 \pm 0.2$ & $7.8 \pm 0.2$ & $7.6 \pm 0.7$ \\
\hline $\mathrm{CB}^{\mathrm{d}}$ & $2.9 \pm 0.5$ & $3.9 \pm 0.8$ & $4.0 \pm 0.7$ & $3.9 \pm 0.5$ & $3.7 \pm 0.3$ & $2.5 \pm 0.3$ & $1.6 \pm 0.4$ & $1.5 \pm 0.3$ & $<1.0^{\mathrm{e}}$ & $<1.0$ & $<1.0$ \\
\hline
\end{tabular}

${ }^{a}$ AMGC, Aerobic mesophilic bacteria. ${ }^{b} \mathrm{LC}$, Lactococci. ${ }^{\mathrm{c}} \mathrm{LB}$, Lactobacillus spp. ${ }^{\mathrm{d}} \mathrm{CB}$, Coliform bacteria ${ }^{\mathrm{e}}<1.0$, Under detection limit 
Table II. Composition of Keş cheese during ripening (90 d).

\begin{tabular}{lcccc}
\hline Compositional parameters & \multicolumn{3}{c}{ Time (Days) } \\
& 1 & 30 & 60 & 90 \\
\hline $\mathrm{pH}$ & $4.87 \pm 0.13$ & $4.79 \pm 0.10$ & $4.70 \pm 0.14$ & $4.58 \pm 0.13$ \\
$\mathrm{DM}^{\mathrm{a}}(\%)$ & $64.46 \pm 0.72$ & $72.75 \pm 0.54$ & $77.54 \pm 0.48$ & $82.52 \pm 0.72$ \\
$\mathrm{SDM}^{\mathrm{b}}(\%)$ & $1.90 \pm 0.09$ & $2.56 \pm 0.44$ & $2.84 \pm 0.61$ & $3.16 \pm 0.45$ \\
\hline
\end{tabular}

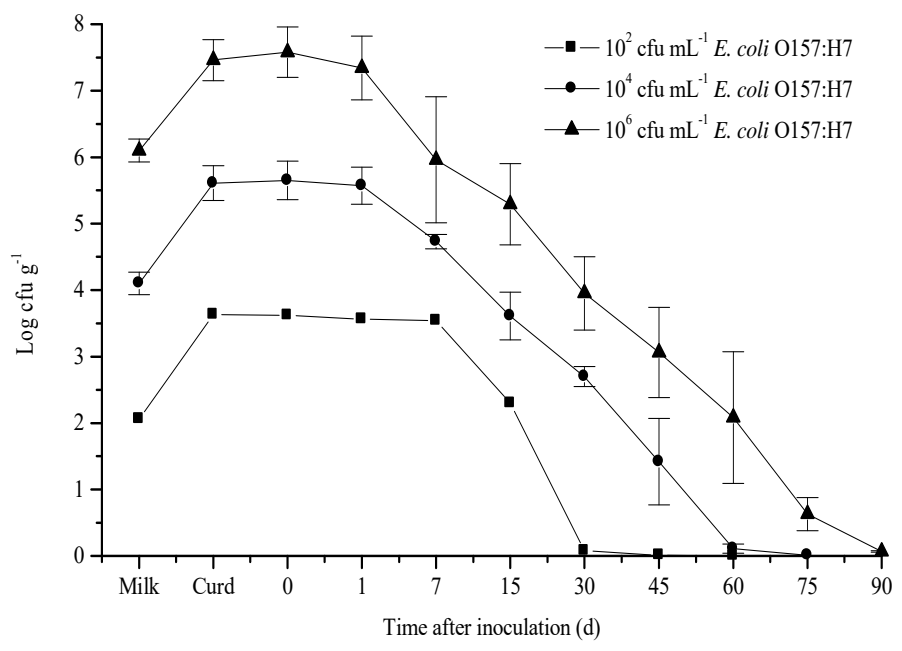

Figure 1: The survival of E. coli O157:H7 (102, 104 or $106 \mathrm{cfu} \mathrm{mL}-1)$ during manufacturing and ripening stages of Keş cheese.

The increasing, stabilizing and remaining at about $10^{4} \mathrm{cfu} \mathrm{g}^{-1}$ for 75 days of E. coli O157:H7 connected with the low $\mathrm{pH}$ level of the cheese $(\mathrm{pH}$ $5.0)$ by the researchers. Also, Kuplulu et al. (2000) reported that the number of E. coli O157:H7 increased $1 \log$ cycle in the curd for all three inoculation levels $\left(10^{2}, 10^{4}\right.$, and $\left.10^{6} \mathrm{cfu} \mathrm{mL}^{-1}\right)$. E. coli $\mathrm{O} 157: \mathrm{H} 7$ is most resistant to stress and lactic acid in late log phase (Benjamın \& Datta, 1995) and stationary phase (Buchanan and Edelson 1999). This knowledge may explain the number of E. coli O157:H7 remain constant at the begining of ripening stage in the present study.

Elimination times of E. coli $\mathrm{O} 157: \mathrm{H} 7$ were determined as 45 day for $10^{2} \mathrm{cfu} \mathrm{mL}^{-1}, 75$ day for $10^{4} \mathrm{cfu} \mathrm{mL}^{-1}$, and 90 day for $10^{6} \mathrm{cfu} \mathrm{mL}^{-1}$ in this study. According to the physico-chemical properties of cheese, $\mathrm{pH}$ level began to slow down after the first day, and reached to $\mathrm{pH} 4.58$ after 90 days (Table II). In addition, dry matter (DM) content was quite high during the ripening period. Salt content in dry matter (SDM) increased from $1.90 \%$ to $3.16 \%$ at the end of the ripening period (Table II). There was a positive correlation between the numbers of $10^{2} \mathrm{cfu} \mathrm{mL} \mathrm{m}^{-1} \mathrm{E}$. coli O157:H7 sample group and $\mathrm{pH}(\mathrm{r}: 0,628 ; \mathrm{P}=0,029)$,
DM (r: $-0,829 ; P<0.001)$, and SDM (r: $-0,758 ; \mathrm{P}=$ 0,004 , Spearman). Similarly, there were a positive correlation between high inoculated groups $\left(10^{4}\right.$ and $10^{6} \mathrm{cfu} \mathrm{mL}^{-1}$ E. coli $\mathrm{O} 157: \mathrm{H} 7$ ) and each physico-chemical properties of cheese. The statistical analysis results for $10^{4} \mathrm{cfu} \mathrm{mL} \mathrm{L}^{-1} E$. coli O157:H7 sample group were r: $0.975, P<0.05$ for $\mathrm{pH} ; \mathrm{r}:-1.000, P<0.01$ for dry matter; $\mathrm{r}:-0.998$, $P<0.01$ for SDM (Pearson). Also, the results of $10^{6}$ cfu $\mathrm{mL}^{-1} E$. coli O157:H7 sample group were for $\mathrm{pH}, \mathrm{DM}$, and SDM were $\mathrm{r}: 0,711, \mathrm{P}=0,010$; $\mathrm{r}$ : $0,774, \mathrm{P}=0,003$; and $\mathrm{r}:-0,734, \mathrm{P}=0,007$ (Pearson), respectively.

Guraya et al. (1998) notified that salt stimulates the pathogen inactivation. Also, there is a correlation between SDM and E. coli O157:H7 inactivation in this study. Conversely, it was reported that $E$. coli $\mathrm{O} 157: \mathrm{H} 7$ could tolerate $\mathrm{NaCl}$ concentrations as high as $8.5 \%$ by Glass et al. (1992). Salt concentrations of the present study were lower than previous studies

(Arocha et al. 1992, Reitsma and Henning 1996, Kuplulu et al. 2000) but inactivation times of all E.coli O157:H7 doses were less than the previous studies. This can be an indication that also other factors play a role except for the amount of salt 
(3\%) to inactivate the pathogen in Keş cheese. Kuplulu et al. (2000) found the elimination times for $10^{2}, 10^{4}$, and $10^{6} \mathrm{cfu} \mathrm{mL}^{-1}$ doses of E. coli O157:H7 as less than 120 days, 120 days and more than 120 days, respectively. The pathogen survived for 158 days when it is added $3 \log \mathrm{mL}^{-1}$ dose to Cheddar cheese milk (Reitsma and Henning, 1996). On the other hand it was reported that E. coli O157:H7 remained for 30-40 days at $\mathrm{pH} 4.0-4.5$ (Mcingvale et al. 2000). In the present study, $\mathrm{pH}$ values changed from 4.87 at the begining of ripening to 4.58 at the end of 90 day ripening in Keş cheese. In the present study, $\mathrm{pH}$ reduction was longer than the previous studies. However, inactivation time of the pathogen was shorter. According to our results, the correlations between the number of all E. coli O157:H7 doses and $\mathrm{pH}$ values, DM, and SDM counts confirmed the effect of physicochemical properties on the pathogen inactivation. However, the effect of $\mathrm{pH}, \mathrm{DM}$, and SDM counts may be combined with other factors. Addition of the spices (Nigella sativa and cumin) to curd, during the production process of Keş cheese, may be considered as an other inactivation factor as they possess antimicrobial agents.

There are numerous studies on antimicrobial effects of Nigella sativa and cumin ( Sagdic et al. 2002, Nazma and Choudhury 2005, Agaoglu et al. 2007; Enany et al. 2009). Burits and Bucar (2000) analysed Nigella sativa for its essential oils. The researchers reported that according to the GC-MS results, essential oil content is took form from large quantities of thymoquinone, cymene, carvacrol, tanethole, 4-terpineol and longifoline. Carvone, dihydro carvone, limonene and carvacrol are volatil oils of cumin. Also, different studies revealed that Nigella sativa seeds (Toama et al. 1974, Nazma and Choudhury 2005) and cumin have an inhibitory effect on E. coli (Agaoglu et al. 2007). According to another study, Nigella sativa oil extract has significant inhibition on E. coli on both human and animal strains as much as most of the standard antibiotics (Enany et al. 2009). Similarly, Sagdic et al. (Sagdic et al. 2002) reported that cumin extract $(2 \%)$ prevented the growth of E. coli O157:H7. On the contrary, red pepper was reported as ineffective on $E$. coli growth (Agaoglu et al. 2007).

The results of the present study demonstrate that survival of E. coli O157:H7 in the lactic cheese production process is possible. Taking into account that the lack of pasteurisation and/or boiling stage in Keş cheese production, regional differences and cheese making process should be standardized as it may cause outbreaks from raw milk originated pathogens and human sourced contaminations. Considering the survival of even low numbers of E. coli O157:H7 in lactic environment can constitute a big threat to the consumers, it is recommended that Burdur Keş cheese should be ripened at least 90 days for the public health.

\section{ACKNOWLEDGEMENTS}

This study was supported by the Scientific Research Projects Unit of Mehmet Akif Ersoy University (Project no: NAP-0006-07).

\section{REFERENCES}

Agaoglu, S., Dostbil, N., \& Alemdar, S. 2007. Antimicrobial activity of some spices used in the meat industry. Bulletin of the Veterinary Institute in Pulawy 51, 53-57.

Akyüz, N., \& Gülümser, S. 1987. Kurutun yapilisi ve bilesimi uzerine bir arastirma. Gida 12 , 185-191.

Arocha, M.M., McVey, M., Loder, S.D., Rupnow, J.H. \& Bullerman, L. 1992. Behaviour of enterohemorrhagic E. coli O157:H7 during the manufacture of cottage cheese. Journal of Food Protection 55, 379-381.

Benjamin, M.M., \& Datta, A.R. 1995. Acid tolerance of enterohemorrhagic Escherichia coli. Applied and Environmental Microbiology 61, 1669-1672.

Buchanan, R., \& Edelson, S. 1999. pH dependent stationary phase acid resistance response of enterohemorrhagic Escherichia coli in the presence of various acidulants. Journal of Food Protection 62, 211-218.

Burits, M., \& Bucar, F. 2000. Antioxidant activity of Nigella sativa essential oil. Phytotherapy Research 14, 323-328.

Coia, J.E. 1998. Clinical, microbiological and epidemiological aspects of Escherichia coli O157:H7 infection. FEMS Immunology and Medical Microbiology 20, 1-9.

Conedera, G., Dalvit, P., Martini, M., Galiero, G., Gramaglia, M., Goffredo, E., \& et al. 2004. Verocytotoxin-producing Escherichia coli O157 in minced beef \& dairy products in Italy. International Journal of Food Microbiology 96, 67-73.

Enany, M.E., El Gohary, A., \& El Dieb, H.A.R. 2009. Studies on antibacterial effect of Nigella sativa on E. coli isolated from human and animal sources. Suez Canal Veterinary Medicine Journal 14, 167-176.

Food \& Drug Administration. 1984. Bacteriological analytical manual (6th edn) 
Association of Official Analytical Chemists Inc, Arlington, V.A.

Glass, K.A., Loeffelholz, J.M., Ford, J.P., \& Doyle, M.P. 1992. Fate of Escherichia coli O157:H7 as affected by $\mathrm{pH}$ or sodium chloride and in fermented, dry sausage. Applied and Environmental Microbiology 58, 2513-2516.

Guraya, R., Frank, J.F., \& Hassan, A.N. 1998. Effectiveness of salt, $\mathrm{pH}$, and diacetyl as inhibitors for Escherichia coli O157:H7 in dairy foods stored at refrigeration temperatures. Journal of Food Protection 61, 1098-1102.

Honish, L., Predy, G., Hislop, N., Chui, L., Kowalewska-Grochowska, K., Trottier, L. \& et al. 2005. An outbreak of E.coli O157:H7 hemorrhagic colitis associated with unpasteurized Gouda cheese. Canadian Journal of Public Health 96, 182-184.

International Dairy Federation. 1958. Determination of dry matter in cheese and processed cheese, Standard 4. International Dairy Federation, Brussels, Belgium.

International Dairy Federation. 1988. Determination of salt content, Standard 12 B. International Dairy Federation, Brussels, Belgium.

Kırdar, S.S. 2004. A research on Keş cheese. In recent developments in dairy science and technology; International Dairy Symposium, Süleyman Demirel University, May 24-28, 2004, Isparta - Turkey, 239-241.

Kuplulu, O., Kasımoğlu, A., \& Akgün, S. 2000. Survival of E. coli O157:H7 during the manufacturing andripening of the Turkish white brined cheese. Veterinary Journal of Ankara University 46, 337-346.

Maher, M.M., Jordan, K.N., Upton, M.E., \& Coffey, A. 2001. Growth and survival of $E$. coli O157:H7 during the manufacture and ripening of smear-ripened cheese produced from raw milk. Journal of Applied Microbiology 90, 201-207.

McIngvale, S.C., Chen, X.Q., McKillip, J.L., \& Drake MA. 2000. Survival of Escherichia coli $\mathrm{O} 157: \mathrm{H} 7$ in buttermilk as affected by contamination point and storage temperature. Journal of Food Protection 63, 441-444.

Nazma, A., Choudhury, S.A.R., \& Amin, R. 2005. In vitro antimicrobial activity of the volatile oil of Nigella Sativa linn seeds. The Journal of Teachers Association 18(2), 109-112.

Öksüz, O., Arıcı, M., Kurultay, S., \& Gümüş, T. 2004. Incidence of Escherichia coli O157 in raw milk and white pickled cheese manufactured from raw milk in Turkey. Food Control 15, 453-456.

Ramsaran, H., Chen, J., Brunke, B., Hill, A., \& Griffiths, M.W. 1998. Survival of bioluminescent Listeria monocytogenes and Escherichia coli O157:H7 in soft cheeses. Journal of Dairy Science 81, 1810-1817.

Reitsma, C.J., \& Henning, D.R. 1996. Survival of enterohemorrhagic Escherichia coli O157:H7 during the manufacture and curing of cheddar cheese. Journal of Food Protection 59, 460-464.

Riley, L.W., Remis, R.S., Helgerson, S.D., McGee, H.B., Wells, J.G., Davis, B.R., \& et al. 1998. Hemorrhagic colitis associated with a rare Escherichia coli serotype. The New England Journal of Medicine 308, 681-685.

Sagdic, O., Kugcu, A,. Ozcan, M., \& Ozcelik, S. 2002. Effects of Turkish spice extracts at various concentrations on the growth of $E$. coli O157:H7. Food Microbiology 19(5), 473-480.

SPSS. 1999. SPSS 10 for windows. Chicago, IL: SPSS Inc.

Tarakci, Z., Kucukoner, E., \& Yurt B. 2001. Ordu ve Yoresinde İmal Edilen Kesin Yapılısı ve Bazı Ozellikleri Uzerinde Bir Arastırma. Gida 26, 295-300.

Tarakci, Z., Dervisoglu, M., Temiz, H., Aydemir, O., \& Yaz1c1, F. 2010. Review on Kes Cheese. Gida 35(4), 283-288.

Toama, A.M., El-Alfy, T.S., \& El-Fatatry, M.H. 1974. Antimicrobial activity of the volatile oil of Nigella sativa linneaus seeds. Antimicrobial Agents and Chemotherapy 6, 225-226.

Zhao, T., Doyle, M.P., Shere, J., \& Garber L. 1995. Prevalence of enterohemorrhagic E. coli O157:H7 in a survey of dairy herds. Applied and Environmental Microbiology 61, 12901293.

Wang, G., Zhao, T., \& Doyle M.P. 1996. Fate of enterohemorrhagic Escherichia coli O157:H7 in bovine feces. Applied and Environmental Microbiology 62, 25672570 . 